\title{
Praktik Higiene Personal dan Keberadaan Bakteri Escherichia coli Pada Tangan Penjual Petis (Studi di Pasar Anom Kecamatan Sumenep Kabupaten Sumenep) \\ Personal Hygiene Practice and Existence of Escherichia coli Bacteria In Fish Paste Seller's Hand (Study in Anom Market of Sumenep District of Sumenep Regency)
}

\author{
Yuli Rukmi Hasanah ${ }^{1}$, Ellyke ${ }^{1}$, Prehatin Trirahayu Ningrum ${ }^{1}$ \\ Bagian Kesehatan Lingkungan dan Kesehatan Keselamatan Kerja, Fakultas Kesehatan Masyarakat, \\ Universitas Jember \\ Jalan Kalimantan 37 Kampus Tegal Boto Jember 68121 \\ Email korespondensi: yulirukmi18@gmail.com
}

\begin{abstract}
Personal hygiene practices in food processing must be considered as a potential source of food handlers in the transfer of microorganisms that can cause food contamination. Fish Peste is the commodity from the fish processing which is usually used as a side dish or a typical mix of traditional food. On the other hand, fish paste is a food that is served without reheating and directly without the use of tools such as spoons or plastic gloves so it can be potentially contaminated with bacteria such as Escherichia coli. Research is aimed to identify how the personal hygiene practices and the presence of Escherichia coli bacteria on the hands of the fish paste sellers placed in open containers in Anom Market of Sumenep district of Sumenep regency. The research was descriptive with quantitative approach. The sample uses a total sampling of 15 respondents fish paste seller. The results of this study indicate that the practice of personal hygiene, most of the 12 respondents categorized of adequate personal hagiene practices, among others from contagious diseases, nails and hands hygiene, hair hygiene, clothing hygiene, wash hands thoroughly, and use tools when handling food. From the results of laboratory test, the samples hands of fish paste seller there were 3 respondents were positive presence of Escherichia coli.
\end{abstract}

Keywords: Personal Higyene Practice, Fish Paste, and Escherichia coli Bacteria

\begin{abstract}
Abstrak
Praktik higiene personal dalam pengolahan makanan harus diperhatikan karena penjamah makanan merupakan sumber potensial dalam perpindahan mikroorganisme yang dapat meyebabkan kontaminasi pada makanan. Petis merupakan komoditi hasil pegolahan ikan yang biasanya digunakan sebagai lauk pauk atau campuran makanan rakyat yang khas. Disisi lain, petis disajikan tanpa melalui pemanasan kembali dan pengemasannya tanpa menggunakan alat bantu seperti sendok atau sarung tangan plastik, sehingga dapat berpotensi terkontaminasi bakteri seperti bakteri Escherichia coli. Penelitian ini bertujuan untuk mengidentifikasi bagaimana praktik higiene personal dan keberadaan bakteri Escherichia coli pada tangan penjual petis yang ditempatkan di wadah terbuka di Pasar Anom Kecamatan Sumenep Kabupaten Sumenep. Penelitian ini menggunakan metode peneltian deskriptif dengan pendekatan kuantitatif. Sampel penelitian ini menggunakan total sampling yakni berjumlah 15 responden penjual petis. Hasil penelitian ini menunjukkan bahwa praktik higiene personal, sebagian besar 12 responden termasuk kategori praktik hagiene personal yang cukup, diantaranya meliputi tidak menderita penyakit menular, kebersihan kuku dan tangan, kebersihan rambut, kebersihan pakaian, mencuci tangan dengan benar, dan penggunaan alat bantu pada saat menjamah makanan. Dari hasil pemeriksaan uji laboratorium, sampel telapak tangan penjual petis terdapat 3 responden yang positif keberadaan Escherichia coli.
\end{abstract}

Kata kunci: Praktik Higiene Personal, Petis, dan Bakteri Escherichia coli 


\section{Pendahuluan}

Keamanan pangan merupakan kondisi dan upaya yang diperlukan untuk mencegah pangan dari kemungkinan cemaran biologis, kimia, dan benda lain yang dapat mengganggu, merugikan, dan membahayakan kesehatan manusia serta tidak bertentangan dengan agama, keyakinan, dan budaya masyarakat sehingga aman untuk dikonsumsi [1]. Makanan yang sudah tercemar jika dilihat dari keadaan fisik biasanya tampak tidak membahayakan atau tidak ada tanda-tanda kerusakan, misalnya dari segi warna, rasa, dan penampilannya. Hal ini masyarakat sering kali terkecoh dan mengkonsumsi makanan tersebut tanpa adanya rasa curiga sedikitpun. Pekerja merupakan sumber paling besar terhadap pegaruh kontaminasi makanan. Dengan demikian kesehatan dan kebersihan pekerja perlu mendapatkan perhatian yang sungguh-sungguh untuk keamanan mutu produk yang dihasilkannya [2].

Penyakit yang erat kaitannya dengan penyediaan makanan yang tidak higiene dan sering terjadi adalah penyakit dengan gejala diare dan keracunan makanan [3]. Bakteri yang digunakan sebagai indikator untuk mengetahui kontaminasi bakteriologi dalam makanan adalah Escherichia coli. Escherichia coli adalah bakteri bersifat gram negatif, berbentuk batang dan tidak membentuk spora, mikroorganisme ini tidak umum hidup atau terdapat dalam air, sehingga keberadaannya dalam air dapat dianggap sebagai petunjuk terjadinya pencemaran kotoran, baik dari kotoran hewan maupun manusia.

Pada saat ini banyak ditemukan berbagai macam pedagang makanan atau minuman yang ada di lingkungan sekitar kita. Salah satu lingkungan yang padat dengan adanya pedagang adalah lingkungan pasar. Pasar Anom merupakan salah satu pasar utama dan terbesar di Kecamatan Sumenep yang banyak terdapat pedagang dengan berbagai macam makanan tradisonal yang dijual, salah satunya adalah petis. Petis adalah komoditi hasil pengolahan ikan yang biasanya digunakan sebagai lauk pauk atau campuran makanan rakyat yang khas [4]. Menurut Bappeda Jawa Timur (2013) menyatakan bahwa petis ikan banyak ditemukan di Timur Pulau Madura yaitu Sumenep. Berdasarkan data dari Dinas Perindustrian dan Perdagangan Kabupaten Sumenep (2016) terdapat 137 unit usaha petis dengan bahan dasar kaldu ikan.

Petis memiliki potensi pasar yang bagus di Indonesia sebagai bumbu perlengkap makanan dengan kandungan protein yang cukup tinggi.
Disisi lain, petis dijualnya secara berkala dengan tempat penyimpanannya yang lembab dan tidak melalui pemanasan kembali, serta pada saat dikemasnya ditangani secara langsung tanpa menggunakan alat bantu seperti sendok atau sarung tangan plastik. Hal ini dapat berpotensi dan berisiko tinggi terkontaminasi mikroba. Berdasarkan SNI 7388:2009 menyatakan bahwa batas maksimum Escherichia coli pada ikan dan produk perikanan lainnya adalah $<3 / \mathrm{g}$.

Beradasarkan studi pendahuluan pada bulan januari 2017 yang dilakukan di Pasar Anom Kecamatan Sumenep Kabupaten Sumenep yang merupakan salah satu pasar yang banyak terdapat penjual petis yang ditempatkan di wadah terbuka yaitu sebanyak 15 responden. Hal ini juga ditemukan petis tersebut tidak terdapat tanggal kadaluarsanya, sehingga penjualannya terkadang tidak memperhitungkan lama penyimpanan yang memungkinkan terkontaminasi mikroorganisme. Disisi lain, praktik higiene personal penjual petis sangat buruk. Hal ini ditemukan bahwa responden menggunakan tangan langsung pada saat penyajiannya. Higiene personal dipengaruhi oleh pengetahuan individu sendiri, dimana pengetahuan sangat berpengaruh terhadap mutu kualitas makanan dan meningkatnya risiko kontaminasi bakteri.

Tujuan penelitian ini adalah untuk mengidentifikasi praktik higiene personal dan keberadaan bakteri Escherichia coli di tangan penjual petis yang ditempatkan di wadah terbuka di Pasar Anom Kecamatan Sumenep Kabupaten Sumenep.

\section{Metode Penelitian}

Jenis penelitian yang digunakan adalah penelitian deskriptif dengan pendekatan kuantitatif. Penelitian ini dilakukan di Pasar Anom Kecamatan Sumenep Kabupaten Sumenep dan uji laboratorium dilakukan di Balai Besar Teknik Kesahatan Lingkungan dan Pengendalian Penyakit Surabaya. Penelitian ini dilakukan bulan Agustus 2017. Total populasi seluruh penjual petis yang ditempatkan di wadah terbuka yaitu sebanyak 15 responden. Sampel yang digunakan dalam penelitian ini adalah total sampling. Variabel penelitian ini meliputi karakteristik responden, higiene personal, dan keberadaan bakteri Escherichia coli.

Sumber data penelitian adalah data primer dan data sekunder. Data primer yaitu dari hasil wawancara dan observasi, serta uji laboratorium. Sedangkan data sekunder diperoleh dari Dinas Perindustrian dan perdagangan dan Dinas 
Kesehatan Kabupaten Sumenep. Penyajian data dalam penelitian ini berupa narasi da tabel. Analisis data yang dilakukan peneliti dalam hal ini adalah menggunakan univariat bertujuan untuk mendeskripsikan terkait karakteristik responden, higiene personal, dan keberadaan bakteri Escherichia coli, serta menggunakan statistik deskriptif untuk menganalisis data dengan mendiskripsikan atau menggambarkan karakteristik responden dan keberadaan bakteri Escherichia coli, praktik higiene personal dan keberadaan bakteri Escherichia coli.

\section{Hasil Penelitian}

Pasar Anom merupakan pasar utama yang terdapat di Kecamatan Sumenep yang memungkinkan terdapat banyak penjual makanan maupun bahan pangan. Salah satu bahan pangan yang banyak digemari oleh masyarakat Madura khususnya masyarakat Sumenep yaitu petis. Penjualan petis ada 2 macam yaitu petis kemasan dan bukan kemasan (sesuai dengan kebutuhan konsumen). Petis merupakan jenis pangan yang siap saji tanpa melalui pemanasan kembali dan ditangani tanpa menggunakan alat bantu. Hal ini kemungkinan besar petis tersebut dapat terkontaminasi bakteri, baik berasal dari sanitasi lokasi maupun tangan penjamah atau anggota tubuh lainnya. Penelitian ini juga menggunakan hasil uji laboratorium yang dilakukan untuk mengetahui keberadaan bakteri Escherichia coli pada telapak tangan penjual petis yang diambil dengan cara mengusap atau swab tangan penjual. Uji laboratorium dilakukan di BTKLPP Surabaya. Responden dalam penelitian ini adalah penjual petis sebanyak 15 orang yang berada di Pasar Anom Kecamatan Sumenep Kabupaten Sumenep. Sampel penelitian yang digunakan untuk uji laboratorium merupakan hasil swab/usap telapak tangan pada tangan yang bekerja aktif atau tangan kanan penjual petis. Karakteristik responden secara terperinci berdasarkan umur, pendidikan terakhir, dan pengetahuan sebagai berikut:

Tabel 1. Distribusi Karakteristik Responden Berdasarkan Umur dan Tingkat Pendidikan Terakhir

\begin{tabular}{clcc}
\hline No. & $\begin{array}{c}\text { Karakteristik } \\
\text { Responden }\end{array}$ & $\mathrm{n}$ & $\%$ \\
\hline 1 & Umur & & \\
\hline & $40-<60$ ahun & 13 & 86,7 \\
& $\geq 60$ tahun & 2 & 13,3 \\
\hline$\quad$ Jumlah & 15 & 100 \\
\hline 2 & Pendidikan Terakhir & & \\
\hline$\quad$ Tidak Sekolah & 5 & 33,3 \\
\hline No. & Karakteristik & $\mathrm{n}$ & $\%$ \\
\hline
\end{tabular}

\begin{tabular}{|c|c|c|c|}
\hline \multicolumn{4}{|c|}{ Responden } \\
\hline & Pendidikan Dasar & & \\
\hline & a. Tamat SD/MI & 8 & 53,3 \\
\hline & b. Tamat & 2 & 13,3 \\
\hline \multicolumn{4}{|c|}{ SMP/MTS } \\
\hline \multicolumn{4}{|c|}{ Jumlah } \\
\hline \multicolumn{4}{|c|}{ Pegetahuan } \\
\hline & Tinggi & 2 & 13,3 \\
\hline & Cukup & 13 & 86,7 \\
\hline & Jumlah & 15 & 100 \\
\hline
\end{tabular}

Berdasarkan tabel 1 dapat diketahui bahwa sebagian besar responden berusia $40-<60$ tahun yaitu sebanyak 13 orang $(86,7 \%)$, dan pada tingkat pendidikan terakhir menunjukkan sebanyak 8 orang $(53,3 \%)$ berpendidikan dasar artinya responden penjual petis hanya tamat SD. Berdasarkan pengetahuan menunjukkan bahwa dari 20 pernyataan mengenai praktik higiene personal, mayoritas responden memiliki pengetahuan yang cukup mengenai higiene personal penjamah makanan. Hasil penelitian tersebut didapatkan hasil bahwa seluruh responden menjawab dengan benar mengenai bagaimana kuku yang bersih dan syarat penjamah makanan yaitu tidak bersin didekat makanan, serta tidak ada responden yang menjawab dengan benar mengenai air bersih untuk mencuci tangan.

Penilaian yang dilakukan peneliti mengenai variabel praktik higiene personal penjual petis di Pasar Anom Kecamatan Sumenep meliputi tidak menderita penyakit menular seperti diare, kebersiha kuku dan tangan, kebersihan rambut, kebersihan pakaian, mencuci tangan dengan benar, menjamah makanan dengan alat bantu. Secara umum, distribusi praktik higiene personal disajikan pada tabel berikut:

Tabel 2. Distribusi Praktik Higiene Personal Penjual Petis yang ditempatkan di wadah terbuka di Pasar Anom Kecamatan Sumenep Kabupaten Sumenep

\begin{tabular}{clcc}
\hline No. & $\begin{array}{c}\text { Praktik Higiene } \\
\text { personal }\end{array}$ & $\mathrm{n}$ & $\%$ \\
\hline 1. & Cukup & 12 & 80,0 \\
2. & Buruk & 3 & 20,0 \\
\hline & Total & 15 & 100,0 \\
\hline
\end{tabular}

Berdasarkan tabel 2 diketahui bahwa sebagian besar responden memiliki tingkat praktik higiene personal yag cukup yaitu sebanyak 12 orang $(80 \%)$. Hasil penelitian tentang praktik higiene personal penjual petis yang ditempatkan di wadah terbuka diperoleh dari enam hal yang dapat memungkinkan bakteri Escherichia coli mengkontaminasi makanan melalui tangan responden. Keenam hal tersebut dapat dilihat riciannya berikut 
a. $\quad$ Tidak Menderita Penyakit Menular (Diare)

Penentuan kejadian diare didasarkan pada saat wawancara kepada responden yang digolongkan pada dua penilaian yaitu ada yang mengalami diare (ya) dan tidak ada mengalami diare (tidak). Berdasarkan hasil penelitian yang dilakukan menunjukkan bahwa tidak terdapat responden yang menderita penyakit diare pada saat wawancara dan observasi. Namun, ada beberapa responden yang mengaku bahwa pernah mengalami diare pada tiga bulan terakhir.

a. Kebersihan Kuku dan Tangan

Hasil penelitian dari kebersihan kuku dan tangan responden penjual petis disajikan pada tabel berikut:

Tabel 3. Distribusi Praktik Higiene Personal Penjual Petis Berdasarkan Kebersihan Kuku dan Tangan

\begin{tabular}{|c|c|c|c|c|c|c|c|}
\hline \multirow[t]{2}{*}{ No } & \multirow{2}{*}{$\begin{array}{c}\text { Kebersihan } \\
\text { Kuku dan } \\
\text { Tangan }\end{array}$} & \multicolumn{2}{|c|}{ Terpenuhi } & \multicolumn{2}{|c|}{$\begin{array}{c}\text { Tidak } \\
\text { Terpenuhi }\end{array}$} & \multicolumn{2}{|c|}{ Total } \\
\hline & & $\mathrm{n}$ & $\%$ & $\mathrm{n}$ & $\%$ & $\mathrm{n}$ & $\%$ \\
\hline 1. & $\begin{array}{l}\text { Tangan dan jari } \\
\text { terlihat bersih }\end{array}$ & 4 & 26,7 & 11 & 73,3 & 15 & 100 \\
\hline 2. & $\begin{array}{l}\text { Kuku tangan } \\
\text { dalam keadaan } \\
\text { pendek dan } \\
\text { bersih }\end{array}$ & 7 & 46,7 & 8 & 53,3 & 15 & 100 \\
\hline 3. & $\begin{array}{l}\text { Tidak } \\
\text { menggunakan } \\
\text { cat kuku }\end{array}$ & 15 & 100 & - & - & 15 & 100 \\
\hline 4. & $\begin{array}{l}\text { Menutup luka } \\
\text { yang terbuka di } \\
\text { tangan }\end{array}$ & 15 & 100 & - & - & 15 & 100 \\
\hline 5. & $\begin{array}{l}\text { Tidak } \\
\text { menggunakan } \\
\text { perhiasan pada } \\
\text { saat menjamah }\end{array}$ & 13 & 86,7 & 2 & 13,3 & 15 & 100 \\
\hline 6. & $\begin{array}{l}\text { Tidak } \\
\text { menyentuh } \\
\text { bagian tubuh } \\
\text { pada saat } \\
\text { menjamah } \\
\text { makanan / } \\
\text { mencuci tangan } \\
\text { sesudahnya }\end{array}$ & - & - & 15 & 100 & 15 & 100 \\
\hline
\end{tabular}

Berdasarkan tabel 3 dapat diketahui bahwa sebagian besar responden memenuhi syarat penilaian yaitu $100 \%$ responden tidak menggunakan cat kuku dan menutup luka yang terbuka ditangan, $86,7 \%$ tidak menggunakan perhiasan, dan sebagian kecil responden memenuhi syarat yaitu 26,7\% memiliki tangan dan jari yang bersih, 46,7\% kuku tangan dalam keadaan pendek dan bersih, serta tidak ada responden yang memenuhi syarat yaitu tidak menyentuh bagia tubuh responden. Hal ini menunjukkan bahwa tidak sedikit penjamah makanan yang belum memenuhi persyaratan menurut KepMenkes tahun 2003. b. Kebersihan Rambut

Penilaian terhadap kebersihan rambut responden penjual petis disajikan pada tabel berikut:

Tabel 4. Distribusi Praktik Higiene Personal Penjual Petis Berdasarkan Kebersihan Rambut

\begin{tabular}{|c|c|c|c|c|c|c|c|}
\hline \multirow[t]{2}{*}{ No } & \multirow{2}{*}{$\begin{array}{l}\text { Kebersihan } \\
\text { Rambut }\end{array}$} & \multicolumn{2}{|c|}{ Terpenuhi } & \multicolumn{2}{|c|}{$\begin{array}{c}\text { Tidak } \\
\text { Terpenuhi }\end{array}$} & \multicolumn{2}{|c|}{ Total } \\
\hline & & $\mathrm{n}$ & $\%$ & $\mathrm{n}$ & $\%$ & $\mathrm{n}$ & $\%$ \\
\hline 1. & $\begin{array}{l}\text { Rambut terikat } \\
\text { rapi }\end{array}$ & 15 & 100 & - & - & 15 & 100 \\
\hline 2. & $\begin{array}{l}\text { Rambut terlihat } \\
\text { bersih (tidak } \\
\text { terdapat } \\
\text { ketombe/kutu/ti } \\
\text { dak lepek) }\end{array}$ & 15 & 100 & - & - & 15 & 100 \\
\hline 3. & $\begin{array}{l}\text { Menggunakan } \\
\text { penutup kepala } \\
\text { (topi) }\end{array}$ & - & - & 15 & 100 & 15 & 100 \\
\hline
\end{tabular}
seluruh responden telah memenuhi syarat penilaian yaitu rambut terikat rapi dan terlihat bersih. Pada penilaian terakhir tidak terdapat responden yang memakai penutup kepala, namun dari 15 responden terdapat 13 responden yang memakai penutup kepala menggunakan kerudung.

c. Kebersihan Pakaian

Hasil penelitian dari kebersihan pakaian responden penjual petis disajikan pada tabel berikut:

Tabel 5. Distribusi Praktik Higiene Personal Penjual Petis Berdasarkan Kebersihan Pakaian

\begin{tabular}{|c|c|c|c|c|c|c|c|}
\hline \multirow[t]{2}{*}{ No } & \multirow{2}{*}{$\begin{array}{c}\text { Kebersihan } \\
\text { Pakaian }\end{array}$} & \multicolumn{2}{|c|}{ Terpenuhi } & \multicolumn{2}{|c|}{$\begin{array}{c}\text { Tidak } \\
\text { Terpenuhi }\end{array}$} & \multicolumn{2}{|c|}{ Total } \\
\hline & & $\mathrm{n}$ & $\%$ & $\mathrm{n}$ & $\%$ & $n$ & $\%$ \\
\hline 1. & $\begin{array}{l}\text { Pakaian yang } \\
\text { digunakan } \\
\text { bersih }\end{array}$ & 10 & 66,7 & 5 & 33,3 & 15 & 100 \\
\hline 2. & $\begin{array}{l}\text { Pakaian yang } \\
\text { digunakan } \\
\text { tidak bermotif }\end{array}$ & 2 & 13,3 & 13 & 86,7 & 15 & 100 \\
\hline 3. & $\begin{array}{l}\text { Pakaian yang } \\
\text { digunakan } \\
\text { berwarna } \\
\text { terang }\end{array}$ & 6 & 40 & 9 & 60 & 15 & 100 \\
\hline 4. & $\begin{array}{l}\text { Pengguaan } \\
\text { celemek yang } \\
\text { bersih }\end{array}$ & - & - & 15 & 100 & 15 & 100 \\
\hline
\end{tabular}

Berdasarkan tabel 5 diketahui bahwa tidak sedikit kebersihan pakaian responden belum memenuhi syarat dikarenakan sebagian besar responden dari segi kebersihan pakaian tidak memenuhi kategori celemek yang bersih dikarenakan responden tidak terbiasa menggunakan celemek pada saat menjamah di 
pasar. Pakaian yang digunakan responden sebanyak 2 responden (13,3\%) tidak bermotif dan 6 responden $(40,0 \%)$ berwarna terang. Namun, sebanyak 10 responden menggunakan pakaian yang bersih.

d. Mencuci Tangan

Hasil penelitian dari mencuci tangan dengan benar responden penjual petis disajikan pada tabel berikut:

Tabel 6. Praktik Higiene Personal Penjual Petis Berdasarkan Mencuci Tangan

\begin{tabular}{|c|c|c|c|c|c|c|c|}
\hline \multirow[t]{2}{*}{ No } & \multirow{2}{*}{$\begin{array}{c}\text { Mencuci } \\
\text { tangan }\end{array}$} & \multicolumn{2}{|c|}{ Terpenuhi } & \multicolumn{2}{|c|}{$\begin{array}{c}\text { Tidak } \\
\text { Terpenuhi }\end{array}$} & \multicolumn{2}{|c|}{ Total } \\
\hline & & $n$ & $\%$ & $\mathrm{n}$ & $\%$ & $n$ & $\%$ \\
\hline 1. & $\begin{array}{l}\text { Tersedia air } \\
\text { bersih untuk } \\
\text { mencuci tangan }\end{array}$ & 2 & 13,3 & 13 & 86,7 & 15 & 100 \\
\hline 2. & $\begin{array}{l}\text { Mencuci tangan } \\
\text { dengan sabun } \\
\text { dan diikuti } \\
\text { pembilasan }\end{array}$ & - & - & 15 & 100 & 15 & 100 \\
\hline 3. & $\begin{array}{l}\text { Mencuci tangan } \\
\text { sebelum } \\
\text { memulai } \\
\text { pekerjaan }\end{array}$ & 3 & 20 & 12 & 80 & 15 & 100 \\
\hline 4. & $\begin{array}{l}\text { Mencuci tangan } \\
\text { setelah } \\
\text { melakukan } \\
\text { aktivitas } \\
\text { apapun }\end{array}$ & 13 & 86,7 & 2 & 13,3 & 15 & 100 \\
\hline 5. & $\begin{array}{l}\text { Menggunakan } \\
\text { pengeringan } \\
\text { tangan dengan } \\
\text { handuk }\end{array}$ & 3 & 20 & 12 & 80 & 15 & 100 \\
\hline
\end{tabular}

tidak sedikit responden belum menerapkan mencuci tangan dengan benar yaitu hanya 2 responden $(13,3 \%)$ tersedia air bersih untuk mencuci tangan, tidak terdapat responden yang memenuhi syarat mencuci tangan dengan sabun dan diikuti dengan pembilasan, 3 responden $(20,0 \%)$ mencuci tangan sebelum memulai pekerjaan dan menggunakan pengeringan tangan. e. Menjamah makanan dengan Alat Bantu

Berdasarkan hasil wawancara dan observasi dapat diketahui bahwa seluruh responden tidak memenuhi syarat dalam menjamah makanan dengan alat bantu yaitu tidak menggunakan alat bantu pada saat mengolah atau menyajikan makanan, pada saat melayani konsumen, dan pada saat mencicipi makanan. Hal ini dikarenakan responden tidak terbiasa memakai alat bantu berupa sedok karena akan memperlambat pekerjaan.

Hasil penelitian dari keberadaan bakteri Escherichia coli pada tangan penjual petis yang ditempatkan diwadah terbuka disajikan pada tabel berikut:
Tabel 7. Keberadaan Bakteri Escherichia coli pada Tangan Penjual Petis yang ditempatkan di Wadah Terbuka

\begin{tabular}{cccc}
\hline No & $\begin{array}{c}\text { Keberadaan Bakteri } \\
\text { Escherichia Coli }\end{array}$ & $\mathrm{N}$ & $\%$ \\
\hline 1 & Positif & 3 & 20 \\
2 & Negatif & 12 & 80 \\
\hline & Total & 15 & 100 \\
\hline
\end{tabular}

Berdasarkan tabel 7 menunjukkan bahwa hasil uji laboratorium keberadaan Escherichia coli pada telapak tangan penjual petis yaitu terdapat 3 responden (20\%) yang positif bakteri Escherichia coli pada telapak tangan. Ketiga responden yang positif bakteri Escherichia coli didapatkan bahwa 2 responden memiliki kategori umur pertengahan (40 - >60 tahun) dan tingkat pendidikan terakhir dasar (tamat SD) serta ketiga responden tersebut memiliki tingkat pengetahuan yang cukup mengenai higiene sanitasi makanan.

Berdasarkan hasil tabulasi silang dengan menggunakan statistik deskriptif diperoleh data praktik higiene personal dan keberadaan Escherichia coli disajikan pada tabel berikut:

Tabel 8. Tabulasi Silang Praktik Higiene Personal dan Keberadaan Escherichia coli

\begin{tabular}{|c|c|c|c|c|c|c|c|}
\hline \multirow{3}{*}{ No. } & \multirow{3}{*}{$\begin{array}{l}\text { Praktik } \\
\text { Higiene } \\
\text { Personal }\end{array}$} & \multicolumn{4}{|c|}{$\begin{array}{l}\text { Keberadaan Bakteri } \\
\text { Escherichia coli }\end{array}$} & \multirow{3}{*}{$\mathrm{N}$} & \multirow{3}{*}{$\%$} \\
\hline & & \multicolumn{2}{|c|}{ Positif } & \multicolumn{2}{|c|}{ Negatif } & & \\
\hline & & $n$ & $\%$ & $\mathrm{n}$ & $\%$ & & \\
\hline 1. & Cukup & 2 & 16,7 & 10 & 83,3 & 12 & 100 \\
\hline 2. & Buruk & 1 & 33,3 & 2 & 66,7 & 3 & 100 \\
\hline
\end{tabular}

Berdasarkan tabel 8 dapat diketahui bahwa pada praktik higiene personal yang memiliki kategori cukup masih ditemukan positif bakteri Escherichia coli sebesar 16,7\%.

\section{Pembahasan}

Menurut Keputusan Menteri Kesehatan RI nomor 942 tahun 2003, menyatakan bahwa dalam melakukan kegiatan pelayanan penanganan makanan jajanan harus memenuhi persyaratan yang meliputi tidak menderita penyakit menular seperti diare, menjaga kebersihan kuku dan tangan, menjaga kebersihan rambut, menjaga kebersihan pakaian, mencuci tangan dengan benar, dan menggunakan alat bantu pada saat menjamah makanan[5]. Berdasarkan hasil penelitian mengenai praktik higiene personal penjual petis yang ditempatkan di wadah terbuka di Pasar Anom Kecamatan Sumenep Kabupaten Sumenep yang berjumlah 15 responden dengan 
22 pertanyaan menujukkan bahwa sebagian besar memiliki praktik higiene personal yang cukup yaitu sebanyak 12 responden $(80 \%)$. Penelitian Cahyarani (2006) juga menunjukkan bahwa kurangnya higiene personal yaitu dari 5 responden sebanyak 4 responden (80\%) tidak menjaga higiene personal mereka [6]. Hal ini dapat terjadi karena responden (penjual petis) kurang memperhatikan aspek-aspek higiene personal yag harus dilakukan dalam menangani atau menjamah makanan.

Berdasarkan hasil penelitian mengenai praktik higiene personal diperoleh dari enam penilaian yang dapat memungkinkan bakteri Escherichia coli megkontaminasi makanan melalui tangan responden yaitu seluruh responden penjual petis tidak menderita penyakit diare. Menurut Purnawijayanti (2001:48) menyatakan bahwa pekerja yang sedang flu, demam dan diare sebaiknya tidak dilibatkan terlebih dahulu dalam proses pengolahan makanan, sampai gejalagejala penyakit tersebut hilang [2]. Hal ini dikarenakan keberadaan bakteri khususnya Escherichia coli terdapat di tinja dan kemungkinan besar akan berpindah ke tangan apabila tidak mencuci tangannya dengan bersih yaitu pemakaian sabun dan air mengalir.

Kuku merupakan salah satu tempat berkumpulnya jasad renik. Kuku yang bersih adalah kuku jari yang dipotong pendek rapi, tidak terdapat kotoran, dan tidak dicat. Pada penelitian ini sebagian besar responden telah memenuhi syarat penilaian yaitu seluruh responden tidak menggunakan cat kuku dan menutup luka yag terbuka, serta sebanyak 13 responden tidak menggunakan perhiasan pada saat menjamah makanan. Namun, masih terdapat responden yang belum memenuhi syarat diantaranya adalah tangan dan jari tidak terlihat bersih $(73,3 \%)$, kuku tangan tidak dalam keadaan pendek dan bersih $(53,3 \%)$, serta selalu menyentuh bagian tubuh pada saat menjamah makanan. Kuku yang pendek dan bersih bertujuan untuk menghindari bersarangnya bakteri yang dapat menularkan penyakit kedalam makanan dan minuman, serta tidak menggunakan pewarna kuku yang dapat memungkinkan besar akan mengelupas dan jatuh kedalam makanan [7]. Penelitian yang dilakukan Mensah et al., (2002) menyatakan bahwa tangan yang kurang bersih akan berpotensi untuk mencemari makanan bila terjadi kontak saat pegolaan makanan[8].

Berdasarkan hasil penelitian mengenai kebersihan rambut didapatkan hasil bahwa sebagian besar responden telah memenuhi syarat yaitu seluruh responden telah mengikat rambutnya dengan rapi dan terlihat bersih, serta tidak menjuntai keluar. Namun, untuk penilaian terakhir yaitu seluruh responden tidak menggunakan penutup kepala, 13 responden menutup kepalanya dengan menggunakan kerudung. Selama pegolahan dan peyajian makanan harus dijaga agar rambut tidak terjatuh kedalam makanan. Walaupun dalam penelitian ini rambut tidak terlalu berperan dalam penularan bakteri Escherichia coli, namun apabila terdapat rambut dalam makanan tidak disukai oleh konsumen. Setiap kali tangan menyentuh, menggaruk, menyisir, atau mengikat rambut, tangan, harus segera dicuci sebelum digunakan lagi untuk menangani makanan [9].

Berdasarkan hasil penelitian mengenai kebersihan pakaian didapatkan hasil bahwa sebagian besar responden belum memenuhi syarat kebersihan pakaian diantaranya adalah menggunakan pakaian yang bermotif, berwarna gelap, dan tidak menggunakan celemek yang bersih. Namun, pada penilaian ini sebagian besar responden telah memenuhi syarat pakaian yang digunakan terlihat bersih. Penelitian Tambekar et al., (2009) menyatakan bahwa pakaian yang kotor pada penjamah makanan dikarenakan kurangnya pengetahuan tentang praktik higiene dan keamanan produk pangan [10].

Berdasarkan hasil penelitian menunjukkan bahwa sebagian besar responden belum memenuhi syarat diantaranya adalah tidak tersedia air bersih sebanyak 13 responden $(86,7 \%)$ artinya air ditampug pada bak air atau ember yang biasanya digunakan bersamaan dengan mencuci tangan dan membilas peralatan yang kotor, seluruh responden tidak mencuci tangan dengan sabun dan diikuti dengan pembilasan, serta tidak mencuci tangan sebelum memulai pekerjaan dan tidak menggunakan pengeringan tangan dengan handuk yang bersih. Perilaku cuci tangan dapat meminimalkan kontaminasi kuman pada kulit. Pencucian tangan yang benar yaitu dengan menggunakan sabun sampai air bersih. Hal ini harus dilakukan sebelum menangani makanan maupun minuman, dan mutlak harus dilakukan ketika seseorang telah menggunakan toilet [11]. Kombinasi antara aktivitas sabun sebagai pembersih, penggosokan, dan aliran air akan menghanyutkan partikel kotoran yang banyak mengandung mikroba [2].

Berdasarkan penelitian mengenai penggunaan alat bantu pada saat menjamah makanan menunjukkan bahwa seluruh responden tidak memenuhi syarat yaitu tidak terdapat responden yag menggunakan alat bantu pada saat mengolah atau menyajikan makanan, melayani konsumen, dan mencicipi makanan. Alasan 
mereka adalah dikarenakan akan memperlambat dalam penyajian dan ketidaknyamanan menggunakan alat bantu pada saat melayani konsumen. Alasan lain menurut mereka, apabila memakai tangan pada saat mengolah petis akan menciptakan keindahan pada warna petis. Penelitian Nurudeen et al., (2013) yang menyatakan bahwa sebagian besar penjamah makanan menyajikan atau menyentuh makanan dengan tangan langsung [12]. Namun berbeda dengan peelitian Cahyarani (2006), hasil penelitiannya menyatakan bahwa 100\% responden menggunakan peralatan sendok makan [7].

Berdasarkan hasil uji laboratorium pada telapak tangan penjual petis yang ditempatkan di wadah terbuka di Pasar Anom Kecamatan Sumenep Kabupaten Sumenep, terdapat 3 responden (20\%) positiif bakteri Escherichia coli. Pada penelitian ini hanya menentukan keberadaan Escherichia coli pada tangan yang aktif atau tangan kanan. Keberadaan Escherichia coli pada telapak tangan penjual petis merupakan indikasi dari kondisi sanitasi yang tidak memadai. Hal ini dapat terjadi dikarenakan dari faktor penjamah makanan yang kurang memperhatikan aspekaspek dari higiene personal. Apabila penjamah makanan melakukan praktik higiene dengan baik dan benar maka akan meminimalisasi tingkat kontaminasi makanan yang disebabkan oleh faktor higiene personal. Pada penelitian ini, penjual petis pada saat proses penyajian atau melayani konsumen tidak menggunakan alat bantu / alas tangan seperti sendok makan dan tidak mencuci tangannnya dengan bersih seperti menggunakan sabun dan air mengalir.

Berdasarkan hasil tabulasi silang menunjukkan bahwa kelompok dengan praktik higiene personal buruk diketahui 1 responden $(33,3 \%)$ dari 3 responden yang dinyatakan positif bakteri Escherichia coli. Kelompok dengan praktik higiene personal yang cukup atau sedang, sebanyak 2 responden (16,7\%) dinyatakan positif bakteri Escherichia coli pada telapak tangan responden (penjual petis). Penelitian Setyorini (2013) menyatakan bahwa ada keterkaitan antara praktik higiene personal dan keberadaan Escherichia coli pada rujak, pada penelitian tersebut membuktikan bahwa praktik higiene personal yang buruk atau kurang baik akan mempengaruhi keberadaan bakteri Escherichia coli sebesar $77,8 \%$ [13]. Penelitian Rachmawati (2015) tentang praktik higiene personal dan keberadaan bakteri Escherichia coli juga membuktikan bahwa ada keterkaitan diantara kedua variabel tersebut, hal ini dapat diketahui bahwa semakin banyak penjamah makanan tidak melakukan praktik higiene personal yang baik, maka semakin besar kemungkinan tangan akan terkontaminasi oleh bakteri Escherichia coli [14].

Selain praktik higiene personal penjamah makanan, sanitasi lokasi tempat penjualan pun juga dapat mempegaruhi keberadaan bakteri Escherichia coli. berdasarkan hasil observasi di lapangan untuk kondisi lantai Pasar Anom sudah terbuat dari semen sehingga dapat dikatakan sudah terbuat dari bahan yang kedap air, namun lantai tersebut terlihat retak dan licin serta lantai dalam kondisi basah karena aktifitas pedagang lainnya yang berdekatan dengan penjual petis yaitu pedagang ikan mencuci tempat dagangannya dan kondisi drenase yang tidak tertutup dan tidak mengalir dengan baik karena tumpukan sampah berasal dari potongan ikan dan sampah bungkusan makanan. Hal ini dapat berpotensi keterpaparan kuman atau mikroorganisme pada pasar sehingga dapat mengkontaminasi makanan yang dijualnya [15].

\section{Simpulan dan Saran}

Karakteristik responden pada penjual petis yang ditempatkan di wadah terbuka di Pasar Anom Kecamatan Sumenep Kabupaten Sumenep diperoleh hasil bahwa sebagian besar responden berumur usia pertengahan atau $40-<60$ tahun, berpendidikan dasar (Tamat SD/MI/SMP/MTS), dan tingkat pengetahuan yang cukup tentang higiene personal penjamah makanan.

Hasil observasi terkait praktik higiene personal penjamah makanan pada penjual petis yang ditempatkan diwadah terbuka di Pasar Anom Kecamatan Sumenep Kabupaten Sumenep diperoleh dari hasil bahwa sebagian besar responden tidak menderita penyakit menular seperti diare; tidak memenuhi syarat kuku dan tangan yang bersih; memenuhi syarat kebersihan rambut namun tidak terdapat responden yang menggunakan penutup kepala; tidak memenuhi syarat kebersihan pakaian seperti pakaian bermotif dan tidak berwarna terang serta tidak menggunakan celemek yang bersih; tidak memenuhi cara mencuci tangan dengan baik seperti dengan menggunakan sabun dan air bersih, serta menggunakan pengering tangan; tidak terdapat responden yang menggunakan alat bantu pada saat menjamah makanan.

Hasil uji laboratorium keberadaan Escherichia coli pada telapak tangan penjual petis yang ditempatkan diwadah terbuka di Pasar Anom Kecamatan Sumenep Kabupaten Sumenep, terdapat 3 responden yang positif bakter 


\section{Escherichia coli.}

Saran yang dapat diberikan bagi Dinas Kesehatan Kabupaten Sumenep adalah perlu adanya program promosi kesehatan dengan memberikan edukasi dan informasi berupa penyuluhan dengan bantuan media poster, leaflet, brosur, audio, dan media lainnya untuk meningkatkan pengetahuan dan perhatian penjamah makanan mengenai higiene sanitasi makanan, serta lebih ketat lagi dalam pengawasan kepada penjual petis yang ditempatkan di wadah terbuka agar memperhatikan higiene sanitasi makanan. Saran untuk pedagang atau penjual yaitu perlu dilakukannya peningkatan higiene personal terutama dalam menjaga kebersihan tangan dengan cara menggunakan alat bantu (sendok makan atau sarung tangan plastik) pada saat menjamah makanan, guna untuk menghindari penyakit bawaan makanan. Saran untuk peneliti selanjutnya yaitu perlu adanya penelitian lanjutan mengenai pemeriksaan laboratorium terkait kandungan mikroba pada petis dan air cuci tangan yang digunakan di Pasar Anom Kecamatan Sumenep Kabupaten Sumenep, serta mengidentifikasi bakteri patogen lain yang terdapat pada petis kemasan dan bukan kemasan.

\section{Daftar Pustaka}

[1] Undang - Undang Nomor 18 Tahun 2012 tentang Pangan

[2] Purnawijayanti, HA. 2001. Sanitasi, Higiene, dan Keselamatan Kerja dalam Pengolahan Makanan. Yogyakarta: Kanisius

[3] Mukono, H.J. 2004. Higiene Sanitasi Hotel dan Restoran Edisi Pertama. Surabaya : Airlangga University Press

[4] Fitriyah, R., Susilo B., Komar, N. 2013. Studi Pengaruh Penambahan Air dan Suhu Pemanasan Terhadap Viskositas Petis Ikan. Jurnal Keteknikan Pertanian Tropis dan Biosistem Vol. 1 No.2, Juni 2013,29-34. Malang: Universitas Brawijaya

[5] Departemen Kesehatan Republik Indonesia. 2003. Keputusan Menteri Kesehatan RI No 942/menkes/SK/VII/2003 tentang Persyaratan Hygiene Sanitasi Makanan Jajanan. Jakarta

[6] Cahyarani, C. 2006. Perbedaan Jumlah MPN Coliform pada Petis Ikan Kemasan dan Bukan Kemasan yang Beredar di Pasar Baru Kamal Madura. Skripsi. Surabaya: Universitas Airlangga

[7] Widyati dan Yuliarsih. 2002. Hygiene dan Sanitasi Umum dan Restoran. Jakarta : PT. Grasindo
[8] Mensah, P., Yeboah, M., Owusu, D., Ablordey A. Street Foods in Accra, Ghana: How Safe are They?. Journal Bull World Health Organ. 2002;80(7):546-54. Epub 2002 Jul 30. University of Ghana

[9] Fathonah, S., 2005. Higiene dan Sanitasi Makanan. Semarang: UNNES Press

[10] Tambekar D.H., V.J. Jaiswal, D.V. Dhanorkar, P.B.Gulhane and M.N.Dudhane1, 2009. Microbial Quality and safety of street vended fruit juices: A case study of Amravati city. Journal of Food Safety. Vol.10, 2009, p. 7276. Amravati University

[11] Mukono, H.J. 2006. Prinsip Dasar Kesehatan Lingkungan Edisi Kedua. Surabaya : Airlangga University Press

[12] Nurudeen, A.A., Lawan, A.O., and Ajayi, S.A. A survey of hygiene and sanitary practices of street food vendors in the Central State of Northern Nigeria. Journal of Public Health and Epidemiology. Vol. 6(5), pp. 174-181, May 2014. ISSN 2006-9723. Kaduna Polytechnic Nigeria

[13] Setyorini, E. 2013. Hubungan Praktek Higiene Pedagang dengan Keberadaan Escherichia coli Pada Rujak yang Dijual di Sekitar Kampus Universitas Negeri Semarang. Skripsi. Semarang. Universitas Semarang

[14] Rachmawati, R. 2015. Praktik Higiene Personal dan Keberadaan Bakteri Escherichia coli Pada Tangan Penjamah Makanan (Studi pada Pedagang Kaki Lima di Jalan Kalimantan Kecamatan Sumbersari Kabupaten Jember). Skripsi. Jember. Universitas Jember

[15] Departemen Kesehatan Republik Indonesia. 2008. Keputusan Menteri Kesehatan Republik Indonesia Nomor 519/Menkes/SK/VI/2008 Pedoman Penyelenggaraan Pasar Sehat. Jakarta 